\title{
FARM SUCCESSION PLANS AMONG POULTRY FARMERS IN OGUN STATE
}

\author{
Fasina O., Inegbedion S., Researchers \\ Federal University of Technology, Akure, Nigeria \\ Email: royalambfuta@gmail.com
}

\begin{abstract}
Ageing of farmers in Nigeria and especially in capitalized sectors of agriculture requires attention to enhance sustainability and food security. The study thus examined the farm succession plans of 60 long established poultry farmers purposively selected from the Poultry Association of Nigeria in Ogun State Nigeria. Descriptive statistics and the Chi square analysis were used to present the findings of the study. Mean age of respondents was 61 years. Their children were mostly over 18years (65\%). Poultry farms were solely owned $(76.7 \%)$ with mean age of 17.9 years. Succession rate i.e. identification of a successor was eighty percent and were mostly respondents children (63.3\%). This choice was based on their level of involvement in the business (63.6\%). Majority (60\%) were not willing to fully retire from farming until death. Chi square analysis revealed age of farmer was significantly related to succession rate $\left(X^{2}=9.80, p \leq 0.05\right)$.
\end{abstract}

\section{KEY WORDS}

Ageing; Poultry; Succession; Retirement; Farmer.

According to the United Nations estimate, nearly 10 percent of the world's population or over 600 million persons are over the age of 60 and this number is expected to double by 2050 (Schwarz, 2003). Ageing which is defined as a steady increase in the population of senior citizen of a country over time, is a socio economic challenge in Africa as nearly twothirds of this elderly group lives in the developing world where formal arrangements for old age support are few. This makes the senior citizens to cling to their jobs and stay longer in active employment than to retire or transfer their business concerns to the next generation.

Nigeria, which is one of the fastest growing economies in Africa, is not exempted from the multiplier effect of ageing, as ageing diminishes the capacity of its people to work and earn which is most felt in the agricultural sector. This sector is the most important sector of the economy from the stand point of employment, sufficiency in food and fiber and export earnings. However, one big determinant of productivity of the sector is age. As the aging cohort of farm owners continue to farm at a rate, at which the law of diminishing return sets in, there is an inverse relationship between the age of farmers and productivity of the farmers. Despite the knowledge of the diminishing effect of age on farm productivity, farming remains a largely inherited occupation and one in which the transfer of business control and ownership to the next generation is arguably one of the most critical stages in the development of the business (Uchiyama, Lobley, Errington, and Yanagimura, 2008). Occupational succession has thus been a key characteristic of the farming culture and maintaining control of the farm business and ensuring its survival through several generations has been an objective shared by people in farming across countries (Errington, 1998). In the past, withdrawal from productive work by the senior generation in agriculture was often gradual, with the switch from strenuous to less strenuous tasks as people aged (Potter and Lobley, 1992). However, with the current global down turn in the economy of nations and increasing poverty level, there is greater unwillingness of the ageing farmers to hands off farming to the next generation. Many farmers also do not deem it necessary to retire from farming activities as it has become a way of life rather than just an occupation. Thus, succession is not just a single event but is (or should be) a process that takes place over an extended period of time. This is because most farmers do not totally handover farm managerial activities at one time but over a period of time. According to Errington and Lobley (2002), succession is the process of transferring the management of business assets. This may involve the transfer of the management of the "home farm" to a successor (or multiple successors), or it may involve the transfer of the necessary capital to establish a new farm 
business. The rate of succession according to Errington and Lobley (2002) has also been defined as the proportion of farmers with an identified successor.

The poultry business in Nigeria is an important subsector in the agricultural sector and one which involves a high amount of capital outlay and infrastructural acquisition. Proprietors of poultry farms are usually psychologically tied to their investment as it takes a lot of their physical effort and mental activity through their years of investment. Many thus face a dilemma as they grow old as to the decision on what happens to their investment and in other words, who takes over from them. It is to this end that this study was designed to find answers to questions on farm succession plans among poultry farmers in Ogun state Nigeria.

\section{OBJECTIVES OF THE STUDY}

The general objective of the study was to examine farm succession plans among poultry farmers in Ogun state Nigeria. The study specifically:

1. Ascertained the personal characteristics of the respondents;

2. Examined their farm succession plans;

3. Determined the rate of succession among the respondents.

\section{HYPOTHESIS OF THE STUDY}

The hypothesis for this study was stated in the null form and was tested at the 0.05 level of significance.

$\mathrm{Ho}_{1}$ : there is no significant relationship between the socioeconomic characteristics of the respondents and the rate of succession.

\section{SAMPLING TECHNIQUE AND SAMPLING SIZE}

The study was carried out in Ogun state of Nigeria. This was purposively done due to the high prevalence of the poultry enterprise in the state. Three zones (Egba zone, Mowe zone and Remo zone) were purposively selected out of the 6 zones of the Poultry Association of Nigeria (PANOG) in Ogun State due to the concentration of farms that has been in existence for long in the zone. Twenty farms which has been in existence for the past ten (10) years and beyond were chosen from each zone, making a total sample size of sixty (60) farms altogether in the survey. The principal/owner of each farm was interviewed. Primary data was collected for this study through the use of a well structured questionnaire containing open and close ended questions. The questionnaire was subjected to face and content validity so as to ensure that appropriate variables were measured and the actual and relevant information were sought. The reliability of the instrument was subjected to test retest method in order to ascertain the consistency of the instrument at an interval of 2 weeks. The test retest was carried out in Ifedore Local Goverment area of Ondo state.

Descriptive statistical techniques such as mean, percentages, bar chart and pie chart were used to present the findings of the study. Chi square analysis was used to test the significance of the study hypothesis.

\section{RESULTS AND DISCUSSIONS}

Results revealed that majority $(78.3 \%)$ of the respondents who were the principals/owners of the farms were male while $21.7 \%$ were female. This signifies that the males dominated the poultry sector in the study area. This is due to the fact that farming generally is referred to as men's work because of its drudgery nature (Alston, 2000). Distribution of respondents by marital status as shown on Table 1 indicated that over twothird $(81.7 \%)$ of them were married while $1.7 \%$ were single, $13.3 \%$ were widowed and $3.3 \%$ were divorced. The implication of the high proportion of the married is that majority can receive dependable advice from their spouse considering the high risk factor in the poultry business as well as joint planning in the event of retirement from poultry farming. Mean 
number of children for the respondents is 4 with $3.3 \%$ having children aged 40 years and above. Twenty five percent had their children aged between $31-40$ years and $40 \%$ of the respondents had children aged between 18 and 30 years. This implies that majority of the respondent's children were adults. Most will already be involved in one career or the other, which may not be related to the poultry business. This situation thus makes the issue of farm transfer and succession a very germane issue. As many of the respondent's children was not living with their parent, a situation which makes them to be less involved in poultry farming. Majority of respondents (61.7\%) were Christians as against $35 \%$ who were Muslims while $3.3 \%$ of the respondents were traditional worshipers. Religious beliefs could be a key issue in this part of the world as related to farm transfers and inheritances.

Table 1 - Distribution of respondents according to personal characteristics

\begin{tabular}{|c|c|c|}
\hline Characteristics & Frequency $(n=60)$ & Percentage $(100 \%)$ \\
\hline \multicolumn{3}{|c|}{ Sex } \\
\hline Male & 47 & 78.3 \\
\hline Female & 13 & 21.7 \\
\hline \multicolumn{3}{|c|}{ Marital status } \\
\hline Single & 1 & 1.7 \\
\hline Married & 49 & 81.7 \\
\hline Divorced & 2 & 3.3 \\
\hline Widow & 8 & 13.3 \\
\hline \multicolumn{3}{|c|}{ Children Age range } \\
\hline Below 18 & 19 & 31.7 \\
\hline $18-30$ & 24 & 40.0 \\
\hline $31-40$ & 15 & 25.0 \\
\hline Above 40 & 2 & 3.3 \\
\hline \multicolumn{3}{|c|}{ Religion } \\
\hline Christian & 37 & 61.7 \\
\hline Muslim & 21 & 35.0 \\
\hline Traditional & 2 & 3.30 \\
\hline
\end{tabular}

Source: Field survey, 2012.

70 years and above

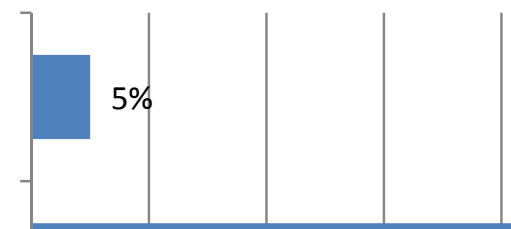

$61-70$ years
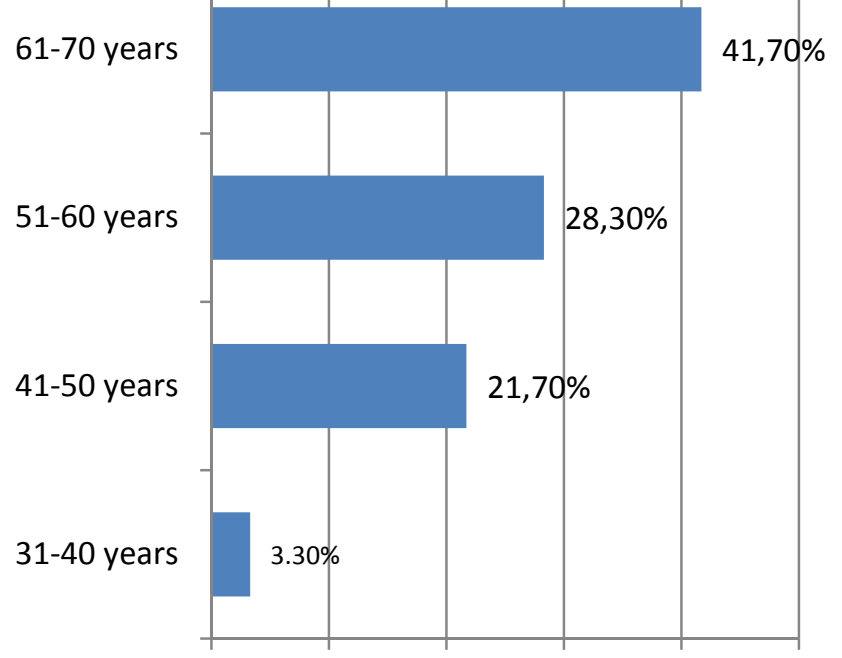

- Percentage

$\begin{array}{lll}0,00 \% & 10,00 \% \quad 20,00 \% \quad 30,00 \% & 40,00 \% \quad 50,00 \%\end{array}$

Figure 1 - Distribution of Respondents by Age in years Source: Field Survey, 2012. 
Figure 1 revealed the distribution of respondents according to age. The mean age however was 61 years with majority falling between the 61 and 70 years category $(41.7 \%)$. This attests to the fact that majority of the respondents who were involved in poultry business in the study area were ageing and therefore not in their active working age. This implies that many of them will be in the process of considering issues on farm succession or continuity of their business. It also implies that the young ones (successors) who are vibrant are not being given the opportunity of managing the farms.

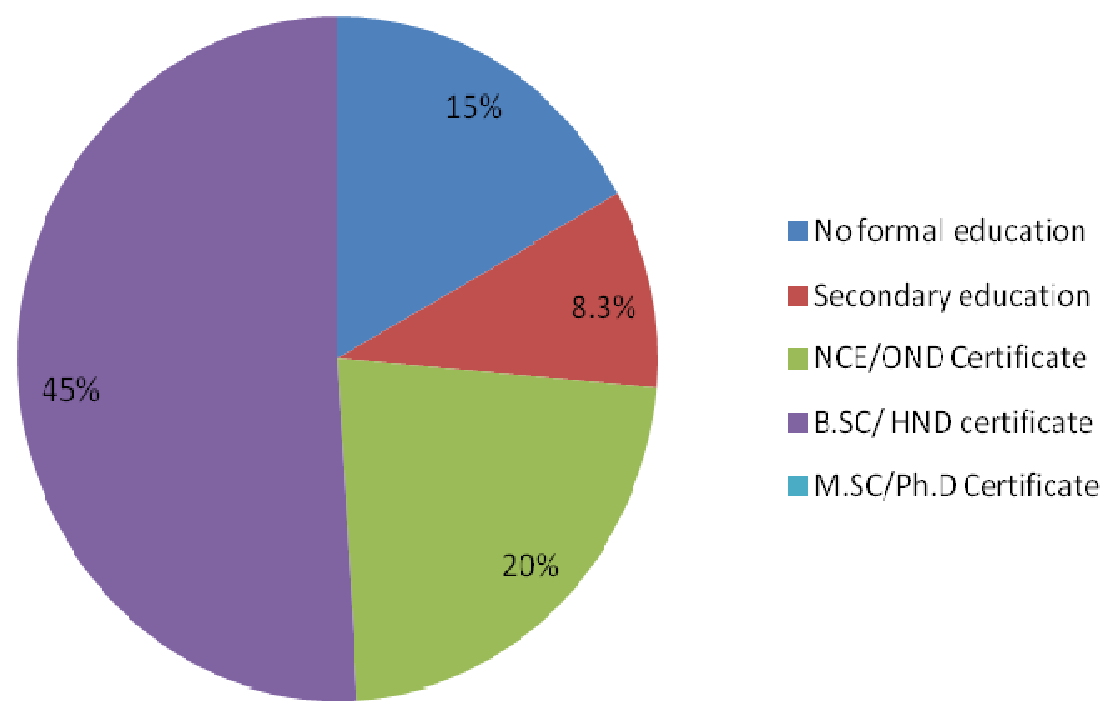

Figure 2 - Distribution of respondents according to the level of educational attainment Sources: Field Survey, 2012.

Figure 2 reveals the distribution of respondents according to level of education. Fifteen percent of the respondents had no formal education, $8.3 \%$ of the respondents had secondary education, $20 \%$ had NCE/OND certificate and the majority (45\%) were BSc /HND holders. Those who had postgraduate degree i.e. MSc/PhD holders were $11.7 \%$. This shows the high level of educational attainment among the respondents. This could be as a result of the technicalities involved in the poultry business which those who are not educated may not be able to cope with. High educational attainment is thus necessary considering the technicalities involved in the poultry business. Furthermore, the high capital outlay for the business makes it necessary to have a steady supply of finance for the business hence many of the entrepreneurs are either retired from public service or still in the service or having another income generating activity. Their educational qualification thus comes into play as they need that to be in a comfortable position in public service.

Majority of the respondents $(56.7 \%)$ were full time poultry farmers while $43.3 \%$ were part time. This may be due to the fact that poultry business needs more attention. Majority of those who were part time farmers were public servants (33.3\%). This category of respondents will be able to invest more in the poultry business with resources coming from their other income generating activities thus increasing their level of profit.

The study revealed that majority $(76.7 \%)$ of the respondents were sole owners of the poultry farms while $18.3 \%$ of the farms were family farms which respondents acquired through family inheritance and $5.0 \%$ were into partnership arrangements. This signifies that farm succession will be a very important agenda on the minds of majority of the respondents.

Majority of the poultry farms $(58.3 \%)$ had been established for between 15-20years followed by those established over 20 years $(25.0 \%)$ and the remaining were between $10-15$ years. Most farms have thus been established for the past average of 17.9years. This means most of the poultry farms have been in existence for long and thus there would have been huge capital investment and some form of emotional attachment to the farms which will make principals not to leave the farm continuity to chances hence they will be concerned about 
farm succession. Years of experience for most respondents in poultry farming was between $11-20$ years $(66.7 \%)$, followed those between $21-30$ years $(20.0 \%), 1-10$ years $(10.0 \%)$ and $31-40$ years (3.3\%). Mean farm experience was 17.1 years revealing a long period of involvement with respect to this type of business involvement

Figure 3 , reveals that majority $(53.3 \%)$ of the respondents had a flock size of between 1,000 to 5,000 birds, followed by $26.7 \%$ whose birds population ranged between 5,001 to 10,000 while $6.7 \%$ of the respondents raised between 10,001 to 15,000 birds and $11.7 \%$ raised more than 15,000 birds in the study area. This shows that the bulk of the respondents were commercial farmers.

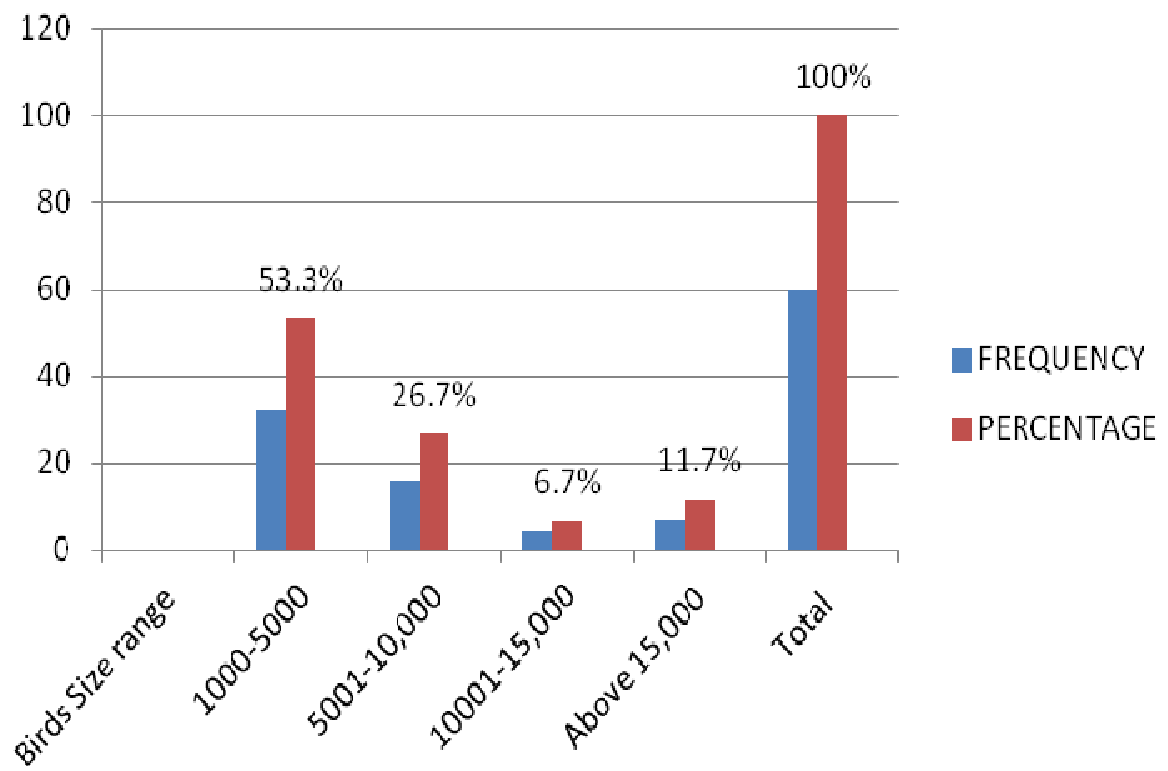

Figure 3 - Distribution of Respondents According to farm flock size Source: Field Survey, 2012.

Majority (58.0\%) of respondents in the study area raised layers while $25 \%$ of the respondents raised broilers, and seventeen percent of the respondents raised cockerels. This signifies that the bulk of farmers in the study area are into egg production. The reason for this significant gap is due to the fact that poultry egg production gives more profit on the long run and the eggs are well consumed generally (Folorunsho and Onibi, 2005).

\section{FARM TRANSFER FEATURES}

Determinants for preferred successor. From Figure 4, major factors that determined respondent's decision on who takes over the farm were presented. Majority $(63.6 \%)$ indicated it will be because of the level of involvement of such a person with them in the running of the farm. This was followed by those who base it on the persons experience in poultry business $(22.0 \%)$. This is closely related with the first reason as the one who is involved will have a better level of experience in the business. Other reasons included interest shown by the individual (11.0\%), hard work/diligence $(7.1 \%)$ and education $(7.1 \%)$. A situation which allows poultry entrepreneur to prefer successor who are committed to poultry work as preferred successor, when taking decision on whom to succeed them in the study area, will boost the farm continued profitability. 


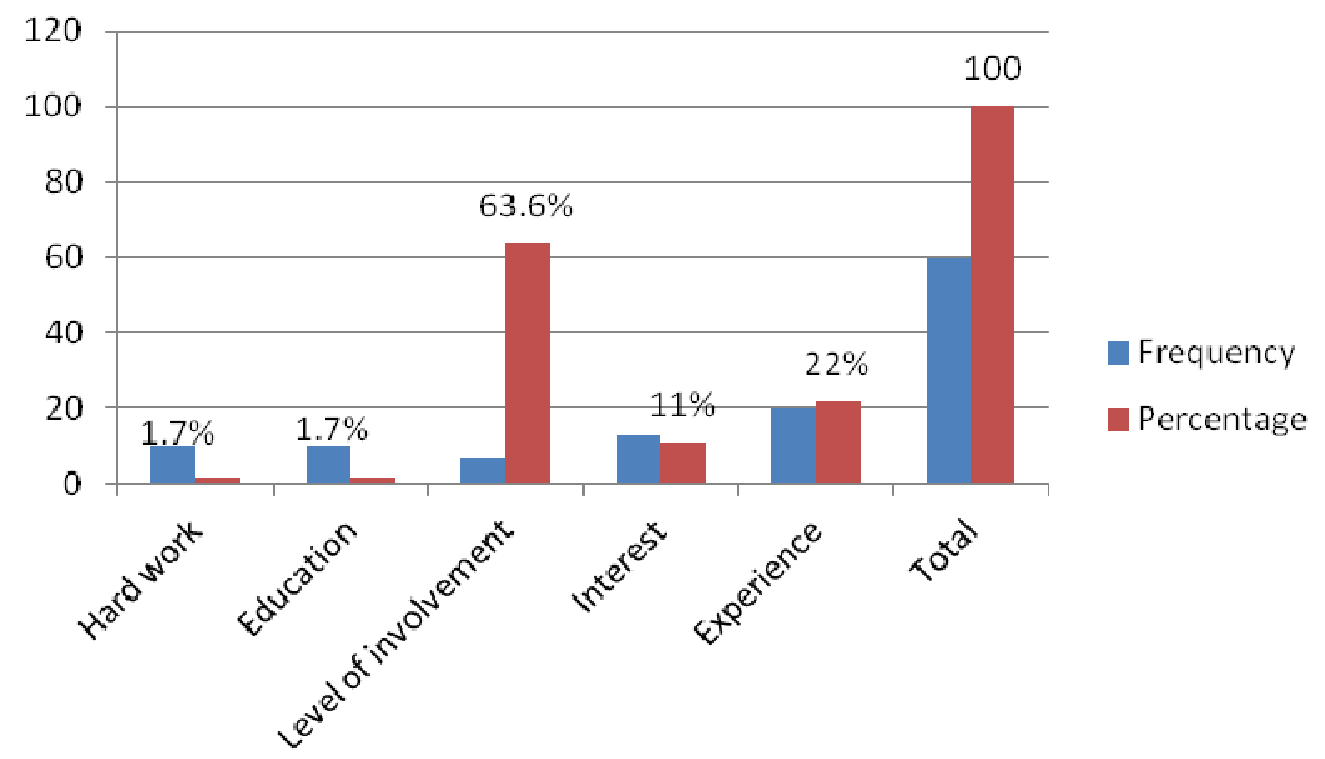

Figure 4 - Distribution of Respondents according to factors determining preference of successor Source: Field Survey, 2012.

Succession rate. Majority $(80 \%)$ claimed to have identified successors, who were dominantly males (89.4\%). This implies a high succession rate (percentage of those who have identified a successor) compared to data from farms in the developed world with England having a succession rate of a little above 50\% (Lobley et al, 2010). Tables 2 further revealed that majority (63.3\%) of the identified successors were one of the children of the respondents. This was followed by successors who were outsiders $(20.0 \%)$ and finally those who were family members/relatives (16.7\%). The pattern of this finding is in line with that identified in England, Australia and other parts of the developed world revealing strong linkages in the transfer of farms within families (Barclay, Foskey, and Reeve, 2005). This is also corroborated by ADAS (2004) which reported that the main entry route into farming remain intergenerational transfer within family. This has implication on the continuity of the poultry business as the owner will not want the business to collapse in its own generation. Furthermore the advantage inherent in this is that if the successor is a child of the principal, in addition to the physical assets inherited, intangible asset (tacit knowledge) are also transferred to the new business (Uchiyama, et al., 2008). Majority (78.3\%) of the respondents did not consider the issue of amalgamation of their farms or going into partnership in later years, while $21.7 \%$ have the issue of amalgamation in mind. This is due to the facts that the bulk of farmers in the study area were sole owners, who prefer family members to inherit the farm and continue with the management rather than an outsider. On the issue of retirement from farming only $40 \%$ indicated that they will fully retire while the rest $(60 \%)$ would only reduce their involvement to the extent their physical health and capacity will allow them. This implies that the takeover of farms in its entirety by successors may not be until the demise of majority of the current proprietors. Thus many of those who ought to take over whether as children or outsiders may have to be engaged in other income generating activities and may make it difficult for them to step aside or abandon their own activities to take over farm management.

Table 2 - Relationship of respondents with successor identified

\begin{tabular}{|c|c|c|}
\hline Relationship of successor & Frequency & Percentage \\
\hline One of the children & 38.0 & 63.3 \\
\hline Relative & 10 & 16.7 \\
\hline Not family member & 12 & 20 \\
\hline Total & 60 & 100 \\
\hline
\end{tabular}

Source: Field Survey, 2012. 
Hypothesis testing. The hypothesis tested in the study was stated in the null form and tested at the 0.05 level of significance. The relationship of the selected socioeconomic characteristics with the identification of a successor was tested with the chi square analysis. The results as shown on Table 3 revealed that only age of the respondents was significantly related with the succession rate $\left(X^{2}=9.80, p \leq 0.05\right)$ i.e. age was a significant factor in the identification or proposal for a successor to the farm. This finding is in tandem with the findings of Lobley et al (2010) in their study of European countries, which shows that the behavior of farmers with regards to succession is fairly the same. This implies that the older the farmer, the more their proneness to begin to consider who succeeds them. This also means that farmers do not consider the issue of succession on time. Thus in the case of unforeseen circumstances like death or disabilities or illness due to old age there could be problems with farm management and consequently succession.

Table 3 - Results of the chi square analysis for the relationship between selected socioeconomic characteristics of respondents and succession rate

\begin{tabular}{|c|c|c|c|c|}
\hline Respondent characteristics & $\mathrm{X}^{2}$ value & Df & p-value & Remark \\
\hline Age & 9.8 & 4 & 0.04 & Significant \\
\hline Sex & 0.09 & 1 & 0.75 & Not Significant \\
\hline Marital status & 1.58 & 3 & 0.66 & Not Significant \\
\hline Level of education & 3.37 & 4 & 0.49 & Not Significant \\
\hline Religion & 0.57 & 2 & 0.75 & Not Significant \\
\hline Farm ownership & 1.24 & 2 & 0.54 & Not Significant \\
\hline Number of wives & 3.57 & 2 & 0.17 & Not Significant \\
\hline
\end{tabular}

Source: Field survey (2012).

\section{CONCLUSION}

In the study's examination of the succession plans of poultry farm proprietors in Ogun State, majority were found to have identified a successor. They were however unwilling to fully retire from active participation for the successors to take over. Age was found to be a significant determinant of succession rate as majority of the respondents was found to be over 50years. Poultry farm proprietors should be given orientation as to the advantage of engaging their successors early in the business so as to make a smooth flow of managerial activities and transfer of technical skills. This will further ensure that they do not work till death do them part with their investment but also take time to rest in their old age while enjoying the fruit of their labour.

\section{REFERENCES}

[1] ADAS Consulting Ltd. 2004. Entry to and exit from farming in the UK (Report to the Department of Environment, Food and Rural Affairs (DEFRA). University of Plymouth, Queen's University Belfast and the Scottish Agricultural College.

[2] Barclay, E., Foskey, R. \& Reeve, I. 2005. Farm succession and inheritance: Comparing Australian and international research. The Institute for Rural Futures, University of New England, Armidale, NSW, Australia.

[3] Errington, A.J. 1998. The intergenerational transfer of managerial control in the farmfamily business: A comparative study in England, France and Canada. Journal of Agricultural Education and Extension, 5, 123-36.

[4] Errington, A. J. \& Lobley, M. 2002. Handing over the reins: A comparative study of intergenerational farm transfers in England, France, Canada and the USA. Paper presented at the meeting of the Agricultural Economics Society, Aberystwyth, UK.

[5] Lobleya, M, Bakerb J. R., and I. Whiteheadc 2010. Farm succession and retirement: Some international comparisons Journal of Agriculture, Food Systems, and Community Development 1, 1, 49-64. 
[6] Potter, C. and Lobley, M. 1992. Ageing and Succession on Family Farms. Sociologia Ruralis, 32, 317-334.

[7] Schwarz, Anita 2003. "Old Age Security and Social Pensions", World Bank: Human Development (Social Protection) Hub: Processed.

[8] Uchiyama T., Lobley M., Errington A., \& Yanagimura S. 2008. Dimensions of intergenerational farm business transfers in Canada, England, the USA and Japan, Japanese Journal of Rural Economics, 10, 33-48. 